\title{
Application of a lagrangian transport model to organo-mineral aggregates within the Nazaré canyon
}

\author{
S. Pando ${ }^{1}$, M. F. Juliano ${ }^{2}$, R. García ${ }^{3}$, P. A. de Jesus Mendes ${ }^{1}$, and L. Thomsen ${ }^{1}$ \\ ${ }^{1}$ Jacobs University Bremen, Oceanlab, Bremen, Germany \\ ${ }^{2}$ LAMTec, Laboratory of Marine Environment and Technology, University of Azores, Praia da Vitória, Azores, Portugal \\ ${ }^{3}$ Instituto Mediterraneo de Estudios Avanzados (CSIC-UIB), Esporles, Balearic Islands, Spain
}

Correspondence to: S. Pando (s.pando@jacobs-university.de)

Received: 8 December 2012 - Published in Biogeosciences Discuss.: 9 January 2013

Revised: 1 May 2013 - Accepted: 11 May 2013 - Published: 20 June 2013

\begin{abstract}
In this study, a hydrodynamic model was applied to the Nazare submarine canyon with boundary forcing provided by an operational forecast model for the west Iberian coast for the spring of 2009. After validation, a lagrangian transport model was coupled to the hydrodynamic model to study and compare the transport patterns of three different classes of organo-mineral aggregates along the Nazaré canyon. The results show that the transport in the canyon is neither constant, nor unidirectional and that there are preferential areas where deposited matter is resuspended and redistributed. The transport of the larger class size of organo-mineral aggregates $(2000 \mu \mathrm{m}$ and $4000 \mu \mathrm{m})$ is less pronounced, and a decrease in the phytodetrital carbon flux along the canyon is observed. During the modelled period, the Nazaré canyon acts as a depocentre of sedimentary organic matter rather than a conduit of organo-mineral aggregates to the deep sea, as has been reported by other authors. The results of this study are crucial for the understanding of the oceanic carbon sequestration at the continental margin, and therefore important for evaluating the role of submarine canyons within the global carbon cycle.
\end{abstract}

\section{Introduction}

Understanding the exchange of energy and matter between the shelf and the open ocean has been the focus of several European research programmes such as OMEX (Wollast and Chou, 2001), EUROSTRATAFORM (Weaver et al., 2006) and HERMES (Weaver and Gunn, 2009). Most recently the HERMES and HERMIONE programmes have addressed the distribution of organic matter, carbon flow and biodiversity in European continental margins (e.g. García et al., 2007; Ingels et al., 2009; Van Oevelen et al., 2011). In these studies submarine canyons are identified as important transport systems of sedimentary organic matter from the continental shelf to the deep ocean (Monaco et al., 1999; Schmidt et al., 2001; Canals et al., 2006), as important depocentres of sediments and organic matter of often higher quality (Epping et al., 2002; Van Weering et al., 2002; De Stigter et al., 2007; García et al., 2008, 2010) as well as hotspots of biodiversity (Ingels et al., 2009; Tyler et al., 2009; Cunha et al., 2011). Consequently, the transport of organic particles in submarine canyons is relevant in terms of global carbon budgets (Thomsen et al., 2002; Accornero et al., 2003; Masson et al., 2010).

Most of the present understanding on the transport of organic particles within submarine canyons has been derived from field observations which have subsequently been summarized in conceptual models of canyon dynamics. The downward transport and the redistribution of sediments and organic particles is controlled by hydrodynamic processes interacting with the bottom topography, such as internal tide circulation, internal waves, the formation of nepheloid layers, down and along slope bottom currents, intermittent gravity flows or the cascading of dense water (e.g. Van Weering et al., 2002; Canals et al., 2006; De Stigter et al., 2007). Hence, submarine canyons which are dominated by the formation of nepheloid layers and internal tides circulation, for example, should mostly concentrate organic material close to the canyon walls; while canyons dominated by down canyon circulation or cascading should mostly transfer organic particles to greater water depths. 
The Nazare submarine canyon is the largest canyon adjacent to the Portuguese coast and has been extensively studied in terms of its geomorphology and sedimentology (Schmidt et al., 2001; Van Weering et al., 2002; De Stigter et al., 2007; Oliveira et al., 2007; Arzola et al., 2008; Lastras et al., 2009), geochemistry (Epping et al., 2002; García et al., 2008; García and Thomsen, 2008) and biology (García et al., 2007; Koho et al., 2007; Ingels et al., 2009; Amaro et al., 2009; Tyler et al., 2009; Cunha et al., 2011). The bulk of the organic matter within the canyon is derived from terrestrial sources (Epping et al., 2002). The oceanographic regime favours the sedimentation of suspended material and burial, which explains the high organic contents and faster depositions in Nazaré canyon (Schmidt et al., 2001; Van Weering et al., 2002; Epping et al., 2002; De Stigter et al., 2007; García et al., 2008). The lateral transport of organic particles through the benthic boundary layer (BBL) is via both aggregation and disaggregation processes as the material is transported in resuspension loops (Thomsen, 1999; de Jesus Mendes et al., 2007) where aggregates are re-shaped and modified into organomineral aggregates (OMAs) (de Jesus Mendes et al., 2007).

The characteristics of marine aggregates collected from depth have been determined for the Iberian continental margin (Thomsen and Gust, 2000; de Jesus Mendes and Thomsen, 2007) but have not been used to date for numerical modelling. The application of lagrangian transport models linked to hydrodynamic models has a high potential to predict various environmental scenarios. At the western Iberian margin, lagrangian transport models have been applied to the Galician coast (Carracedo et al., 2006), Ria de Vigo (Huhn et al., 2012; Abascal et al., 2012), Rio Lima estuary (Vale and Dias, 2011), Ria de Aveiro lagoon (Dias et al., 2001), Óbidos lagoon (Malhadas et al., 2009) and Tagus estuary (Braunschweig et al., 2003). The operational model MOHID-PCOMS (MOdelação HIDrodinâmica Portuguese Coast Operational Modelling System) (Mateus et al., 2012) runs in full operational mode for the western Iberian coast with daily hydrodynamic and ecological results. The model adequately represents the hydrodynamic features of the region and the seasonal variations in the dynamical processes. In this study, the MOHID model simulated the dispersion of OMAs within the Nazaré canyon by coupling the hydrodynamic model to a lagrangian transport model. The simulations in this current study cover several months of spring, a period during which surface phytodetritus production and subsequent transport to benthic communities is of ecological interest. The numerical model was assessed to determine whether it agreed with the flux passing through the upper and middle part of the canyon as described by the current conceptual model of organic matter transport. Lastly, the hypothesis that the Nazaré canyon acts as a conduit for OMAs, and therefore an enhanced carbon flux, was tested.

\section{Methods}

\subsection{Study area}

The western Iberian shelf and slope are intersected by several submarine canyons. The Nazaré canyon is the largest of these extending $\sim 210 \mathrm{~km}$ offshore, from the Nazare beach running down to $5000 \mathrm{~m}$ depth (Tyler et al., 2009). According to Lastras et al. (2009), the canyon can be divided into three sections based on the hydrography and its physical characteristics. The upper section embraces a V-shaped valley incised into the shelf starting at the canyon's head and extending to a depth of $2700 \mathrm{~m}$ and is branched by a short side-valley called Vitória tributary. The middle section is characterized by a broad meandering valley with terrace slopes descending from $2700 \mathrm{~m}$ to $4000 \mathrm{~m}$ depth and the lower section, a flat floored valley which descends to a depth of $5000 \mathrm{~m}$. The canyon cuts the entire Portuguese continental shelf and slope. The hydrodynamic processes are intensified by the rugged topography because the internal waves are preferentially formed in the canyon (Quaresma et al., 2007) and trapped as internal tidal energy. This mechanism is responsible for sediment resuspension and transport at the shelf (Quaresma et al., 2007) and in the upper section of the canyon (De Stigter et al., 2007). Martín et al. (2011) analysed the near bottom particle dynamics for the upper and middle Nazare canyon and determined two contrasting dynamic environments. In the upper section $(1600 \mathrm{~m}$ depth) high current speeds with spring tides up to $80 \mathrm{~cm} \mathrm{~s}^{-1}$ were registered and also high mass fluxes of particulate matter (mean $65 \mathrm{~g} \mathrm{~m}^{-2} \mathrm{~d}^{-1}$; maximum $265 \mathrm{~g} \mathrm{~m}^{-2} \mathrm{~d}^{-1}$ ), while at the deepest station $(3300 \mathrm{~m})$ the mass fluxes were below $10 \mathrm{~g} \mathrm{~m}^{-2} \mathrm{~d}^{-1}$. The authors also concluded that storms can trigger sediment transport at the middle Nazaré canyon.

\subsection{Organo-mineral aggregate data}

The dispersion patterns, residence time estimation and travel trajectories of organic particles of different sizes under spring hydrodynamic conditions were studied. The OMAs of three different size classes (i.e. $429 \mu \mathrm{m}, 2000 \mu \mathrm{m}$ and $4000 \mu \mathrm{m}$ ) were sampled during OMEX I, OMEX II, EUROSTRATAFORM and HERMES cruises to the northeastern Atlantic continental margin (RV Pelagia 95; RV Pelagia 1998; RV Meteor 1998/1999; RV Pelagia 2004) (Thomsen et al., 2002; de Jesus Mendes and Thomsen, 2007). The $429 \mu \mathrm{m}$ aggregates belong to a dominant class of aggregates with the same median aggregate parameter size observed at the western Barents Sea, the northeast Greenland Sea, the Celtic Sea, and the Nazaré and Setúbal canyons (Thomsen and Graf, 1995; Thomsen and Ritzrau, 1996; Thomsen and Van Weering, 1998; de Jesus Mendes and Thomsen, 2007). Frequently these aggregate sizes were found at the shelf and at depths $>2500 \mathrm{~m}$, while aggregates with larger dimensions $(>900 \mu \mathrm{m})$ were found at $3400 \mathrm{~m}$ depth at the northwest 
Iberian continental margin (Thomsen et al., 2002). The median aggregate sizes $(429 \mu \mathrm{m})$ were constituted of organic matter $(\leq 80 \% \mathrm{wt})$ and lithogenic material $(\geq 20 \%)$ while the aggregates with larger dimensions $(2000 \mu \mathrm{m}, 4000 \mu \mathrm{m})$, also known as fluffy phytodetrital aggregates, were constituted of small amounts of lithogenic material and were highly transparent ( $>80 \%$ organic matter).

Critical shear velocities $\left(U_{\text {cr }}^{*}\right)$, critical deposition velocities $\left(U_{\mathrm{d}}^{*}\right)$ and particle settling velocities $\left(W_{\mathrm{s}}\right)$ were determined for the three different aggregate sizes (Thomsen et al., 2002) (Table 1). These velocities were mandatory for the lagrangian model, and their units were converted into the model requirement units.

\subsection{MOHID model}

\subsubsection{Hydrodynamic module}

A high-resolution hydrodynamic model was used to simulate the evolution of the 3-D physical structure of the Iberian coast, and its influence on OMA transport to and within the Nazaré canyon. The model is an open source software under continuous development, named MOHID Water (http: //www.mohid.com), and a component of the MOHID Water Modelling System (MWMS), an integrated water modelling software that simulates water dynamics in water bodies, porous media and watersheds (Mateus, 2012). The MWMS is able to simulate broad processes and scales in marine systems ranging from coastal areas to the open ocean (Coelho et al., 2002; Santos et al., 2002; Santos et al., 2005; Mateus et al., 2012). The hydrodynamic model solves 3-D incompressible primitive equations considering hydrostatic equilibrium and the Boussinesq approximation, and its description can be found in Martins et al. (2001). The turbulent vertical mixing coefficient is determined using the General Ocean Turbulence Model (GOTM).

\subsubsection{Lagrangian transport module}

The lagrangian transport module of MOHID was used to simulate particle transport following the methodologies proposed in previous works (Braunschweig et al., 2003; Saraiva et al., 2007; Malhadas et al., 2009). The lagrangian module simulates the movement of aggregates located at specific water depths using the current fields calculated by the hydrodynamic module, thus solving the equation of transport independent of momentum balance equations. The lagrangian module derives the hydrodynamic information (current fields) from the system and updates the calculations without having the need to solve all variables at the same time. It uses the concept of passive tracers, characterized by their spatial coordinates, area and others properties such as settling velocities, and critical and depositional bottom shear stress (Table 1).
Table 1. OMA characteristic data used in the model simulations: aggregate size $d(\mu \mathrm{m})$; settling velocity $W_{\mathrm{s}}\left(\mathrm{cm} \mathrm{s}^{-1}\right)$; critical and depositional velocities $U_{\mathrm{cr}}^{*}$ and $U_{\mathrm{d}}^{*}\left(\mathrm{~cm} \mathrm{~s}^{-1}\right)$; critical and depositional bottom shear stresses $T_{\mathrm{cr}}$ and $T_{\mathrm{d}}\left(\mathrm{N} \mathrm{m}^{-2}\right)$ (Thomsen et al., 2002; de Jesus Mendes and Thomsen, 2007).

\begin{tabular}{rrrrrr}
\hline $\begin{array}{r}d \\
(\mu \mathrm{m})\end{array}$ & $\begin{array}{r}W_{\mathrm{s}} \\
\left(\mathrm{cm} \mathrm{s}^{-1}\right)\end{array}$ & $\begin{array}{r}U_{\mathrm{cr}}^{*} \\
\left(\mathrm{~cm} \mathrm{~s}^{-1}\right)\end{array}$ & $\begin{array}{r}T_{\mathrm{cr}} \\
\left(\mathrm{N} \mathrm{m}^{-2}\right)\end{array}$ & $\begin{array}{r}U_{\mathrm{d}}^{*} \\
\left(\mathrm{~cm} \mathrm{~s}^{-1}\right)\end{array}$ & $\begin{array}{r}T_{\mathrm{d}} \\
\left(\mathrm{N} \mathrm{m}^{-2}\right)\end{array}$ \\
\hline 429 & 0.001 & 0.72 & 0.050 & 0.058 & 0.003 \\
2000 & 0.303 & 0.61 & 0.038 & 0.5 & 0.030 \\
4000 & 0.477 & 0.50 & 0.026 & & 0.020 \\
\hline
\end{tabular}

In our study, the model simulates the OMA trajectories using the concept of settling velocity, and each particle is assigned a time to perform random movement. These particles are placed at origins which emit the tracers at a specific depth and at one instant in time. The dispersion and distribution field of the particles is monitored using monitoring boxes to compute their residence time. For this project we use the term "residence time" for the temporal interval required by the OMAs to leave each monitor box. This is a new and alternative approach to the previous concept proposed by Braunschweig et al. (2003). The lagrangian results to characterize the OMA behaviour showed the average distance, displacement and velocity of OMAs of different sizes for each box (Figs. 8-10). The distance was related to the total length that the OMAs travelled $(\mathrm{km})$; the displacement was the difference between the initial and final position of the OMAs $(\mathrm{km})$ and the velocity of the OMAs $\left(\mathrm{km} \mathrm{yr}^{-1}\right)$.

\subsection{Model set-up for the Nazaré canyon}

The domain configuration of the Nazare canyon includes three levels of nested models using a one-way coupling (Fig. 1). This nesting methodology is described in Leitão et al. (2005). The first level covers the west coast of Iberia between $5.5-12.6^{\circ} \mathrm{W}$ and $34.4-45.0^{\circ} \mathrm{N}$ with a resolution of $5.6 \mathrm{~km}$. The boundary conditions of this level are provided by the 3-D operational model MOHID-PCOMS (Mateus et al., 2012). The operational model is forced by data from PSY2v2 Mercator Ocean solution for the North Atlantic and by MM5 atmospheric forecast model with $9 \mathrm{~km}$ resolution operated at IST (http://meteo.ist.utl.pt). Tide is imposed from 2-D barotropic model forced by the FES2004 global solution.

The second level covers the stretch from Figueira da Foz to Ericeira between $8.86-10.38^{\circ} \mathrm{W}$ and $39.02-40.08^{\circ} \mathrm{N}$ with a constant grid spacing of $2 \mathrm{~km}$. The third grid has a resolution of $400 \mathrm{~m}$ for the Nazaré canyon area between 9$10.22^{\circ} \mathrm{W}$ and $39.3-39.8^{\circ} \mathrm{N}$. The vertical resolution of the three different levels adopted in this one-way nested modelling scheme is with 50 vertical layers, 43 Cartesian coordinates on the bottom and 7 sigma coordinates on the upper $10 \mathrm{~m}$. The bathymetric data for the levels construction were provided by the National Oceanography Centre, 

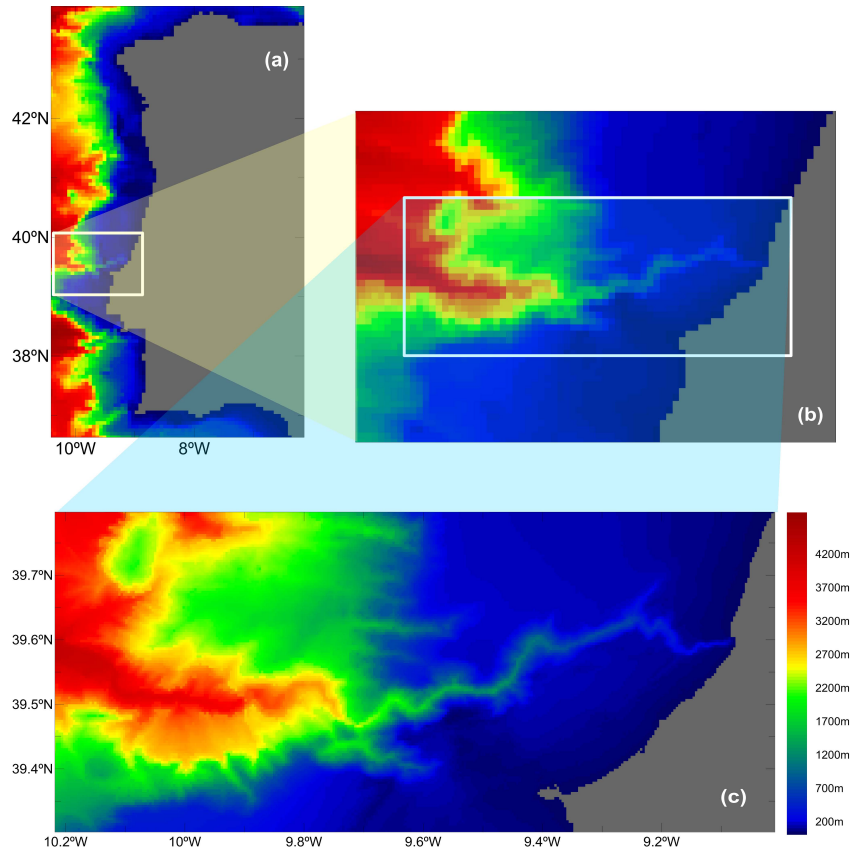

Fig. 1. Nazaré canyon location at the western Iberia margin. The nested domains: (a) first level: MOHID-PCOMS; (b) second level: Figueira da Foz-Peniche; (c) third level: Nazaré canyon.

Southampton (NOCS), and the Portuguese Hydrographic Institute (IH). To cover a period of phytoplankton production, the simulations were conducted during spring season. The model runs from 1 March to 1 July 2009 in order to achieve a proper circulation pattern of the canyon dynamics. The simulations had a time step of $15 \mathrm{~s}$ and a horizontal viscosity of $10 \mathrm{~m}^{2} \mathrm{~s}^{-1}$ for the third level. The first and the second level had a time step of $900 \mathrm{~s}$ and $60 \mathrm{~s}$ and a horizontal viscosity of $30 \mathrm{~m}^{2} \mathrm{~s}^{-1}$ and $20 \mathrm{~m}^{2} \mathrm{~s}^{-1}$, respectively.

The lagrangian module was run with tracers originating from 10 boxes of same dimensions distributed along the Nazaré canyon area at water depths between 59 and $3189 \mathrm{~m}$ (Fig. 2) (Table 2). Each box corresponds to a geographic domain of $3 \times 3$ cells of the model grid leading to a total of $1.44 \mathrm{~km}^{2}$. The boxes were filled with aggregates at a height of $0.5 \mathrm{~m}$ from the sea floor. While applying the module, properties such as the monitor box area and spatial coordinates, OMA settling velocities, and critical and depositional bottom shear stress were taken into consideration. For the OMAs of three different size classes, the settling velocities $\left(W_{\mathrm{s}}\right)$ increased with increasing aggregate size, while the critical shear velocities $\left(U_{\mathrm{cr}}^{*}\right)$ decreased over the same aggregate size spectrum. However, the depositional bottom shear stress $\left(T_{\mathrm{d}}\right)$ is highest for the medium-sized aggregates $(2000 \mu \mathrm{m})$, and has lower values for the $429 \mu \mathrm{m}$ and $4000 \mu \mathrm{m}$ aggregates (Table 1). The boxes were located in the upper (canyon head $-2700 \mathrm{~m}$ ) and middle (2700-4000 m) part of the Nazaré canyon according to Lastras et al. (2009). The first box was located at the canyon's head $(59 \mathrm{~m})$ and box 2 at the shelf
Table 2. Percentage of OMAs escaping from the monitor boxes predicted by the model.

\begin{tabular}{lrrrr}
\hline Box & $\begin{array}{r}\text { Depth } \\
(\mathrm{m})\end{array}$ & $\begin{array}{r}429 \mu \mathrm{m} \\
(\%)\end{array}$ & $\begin{array}{r}2000 \mu \mathrm{m} \\
(\%)\end{array}$ & $\begin{array}{r}4000 \mu \mathrm{m} \\
(\%)\end{array}$ \\
\hline 1 & 59 & 8.38 & 0.05 & 0.75 \\
2 & 262 & 29.74 & 6.04 & 22.31 \\
3 & 357 & 2.05 & 1.75 & 1.65 \\
4 & 575 & 1.60 & 0.95 & 0.95 \\
5 & 331 & 3.90 & 3.30 & 3.30 \\
6 & 945 & 2.30 & 1.70 & 1.70 \\
7 & 1498 & 7.73 & 3.54 & 8.87 \\
8 & 2077 & 16.24 & 2.99 & 27.25 \\
9 & 2657 & 14.36 & 2.49 & 39.38 \\
10 & 3189 & 21.68 & 10.87 & 48.85 \\
\hline
\end{tabular}

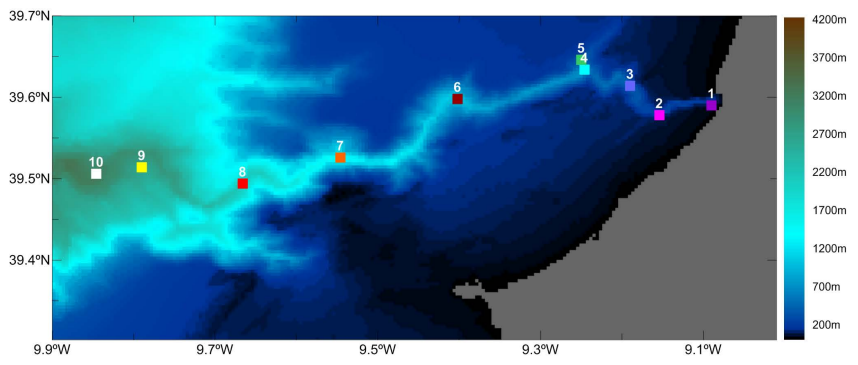

Fig. 2. Location of the 10 monitor boxes. The monitor boxes are set at increasing depths from box 1 to box $10: 59 \mathrm{~m}, 262 \mathrm{~m}, 357 \mathrm{~m}$, $575 \mathrm{~m}, 331 \mathrm{~m}, 945 \mathrm{~m}, 1498 \mathrm{~m}, 2077 \mathrm{~m}, 2657 \mathrm{~m}$, and $3189 \mathrm{~m}$.

break. The third box was located at $357 \mathrm{~m}$ while boxes 4 and 5 were at Vitória's tributary and located at $575 \mathrm{~m}$ and $331 \mathrm{~m}$ respectively. Boxes 6 and 7 were placed at $945 \mathrm{~m}$ and $1498 \mathrm{~m}$ where the Nazaré canyon dynamics are controlled by the Mediterranean Outflow Water (MOW). Boxes 8 and 9 were located close to the boundary between the upper and middle part of the canyon ( $2077 \mathrm{~m}$ and $2657 \mathrm{~m}$ respectively). The last box was located in the middle part of the canyon at $3189 \mathrm{~m}$. The boxes were filled with $\sim 2000$ aggregates of which part escaped from the box depending on the hydrodynamic conditions affecting the box. The validation of the hydrodynamic model was performed with the validation of the MOHID-PCOMS model (Mateus et al., 2012). The following nested levels, including the Nazaré canyon, were also validated allowing the linkage with the lagrangian transport model.

\section{Results}

\subsection{OMAs residence time dynamics}

The residence time of the three OMA classes inside each box for spring 2009 is shown in Figs. 3-5. The oscillation pattern of the three different OMA sizes for box $1(59 \mathrm{~m})$ to box 

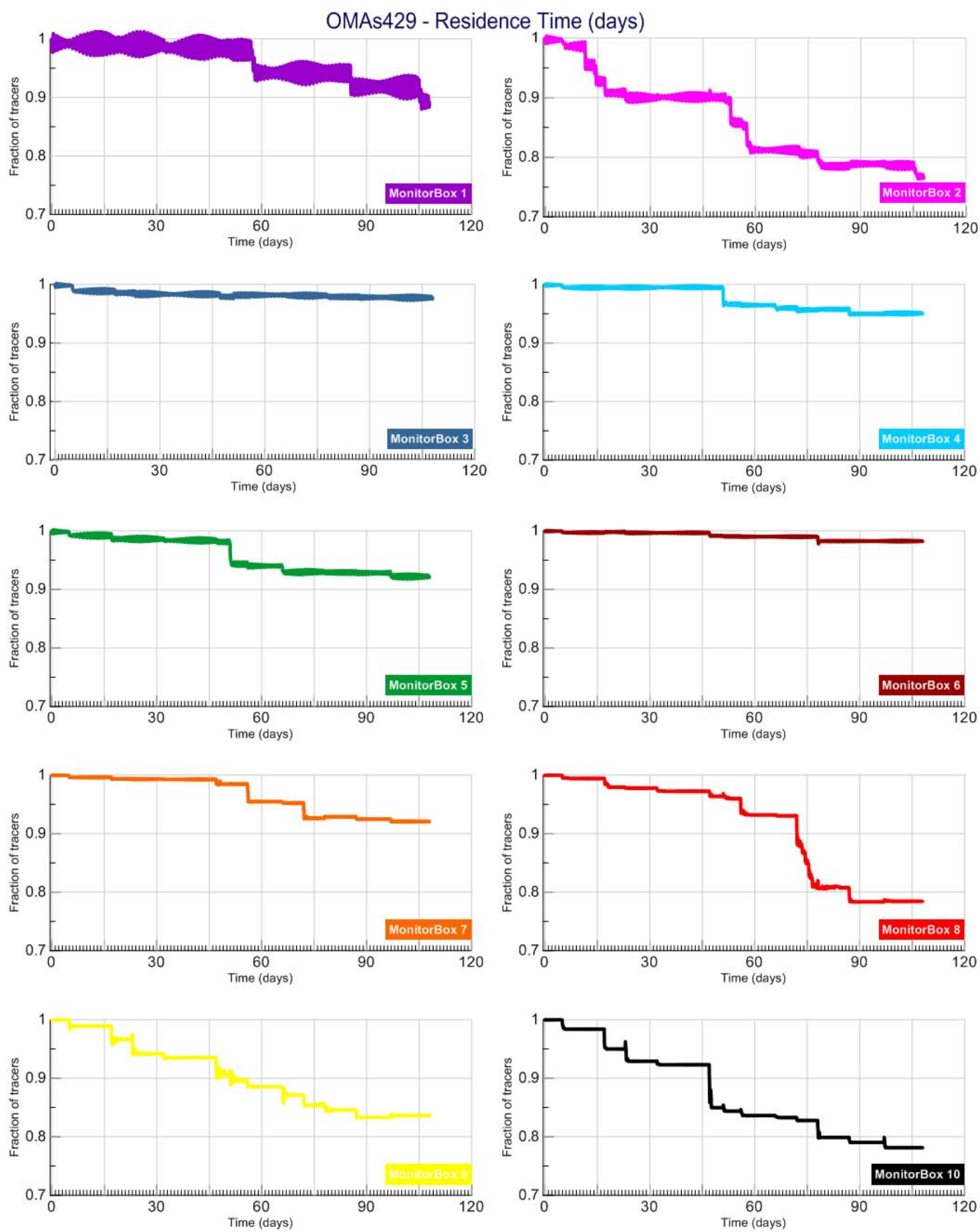

Fig. 3. The residence time of the $429 \mu \mathrm{m}$ OMAs in each monitor box over the simulated period. The monitor boxes are set at increasing depths from box 1 to box 10: $59 \mathrm{~m}, 262 \mathrm{~m}, 357 \mathrm{~m}, 575 \mathrm{~m}, 331 \mathrm{~m}, 945 \mathrm{~m}, 1498 \mathrm{~m}, 2077 \mathrm{~m}, 2657 \mathrm{~m}$, and $3189 \mathrm{~m}$.

$5(331 \mathrm{~m})$ follows the sinusoidal shape of the tide oscillation, being more intense within box 1 , located at $59 \mathrm{~m}$ depth and smoother in the other boxes (Figs. 3-5). The $429 \mu \mathrm{m}$ OMAs at box 1 show transport after 60 days of the simulation period (Fig. 3), while the phytodetrital aggregates ( $2000 \mu \mathrm{m}$ and $4000 \mu \mathrm{m})$ remained in the box without being transported (Figs. 4 and 5). Box 2 at the shelf break showed an abrupt depletion due to transport of the phytodetrital ag- gregates $(2000 \mu \mathrm{m}$ and $4000 \mu \mathrm{m})$ after a period of four days (Figs. 4 and 5), whereas the $429 \mu \mathrm{m}$ OMAs continuously decreased with time inside the box (Fig. 3). The OMAs in boxes $3,4,5$, and 6 had high residence times, indicating a reduced transport of aggregates in this part of the canyon. Box 7 at $1498 \mathrm{~m}$ showed a decrease in the residence times particularly for the $429 \mu \mathrm{m}$ and $4000 \mu \mathrm{m}$ (Figs. 3 and 5). The model predictions for boxes 8,9 , and 10 located offshore showed a 

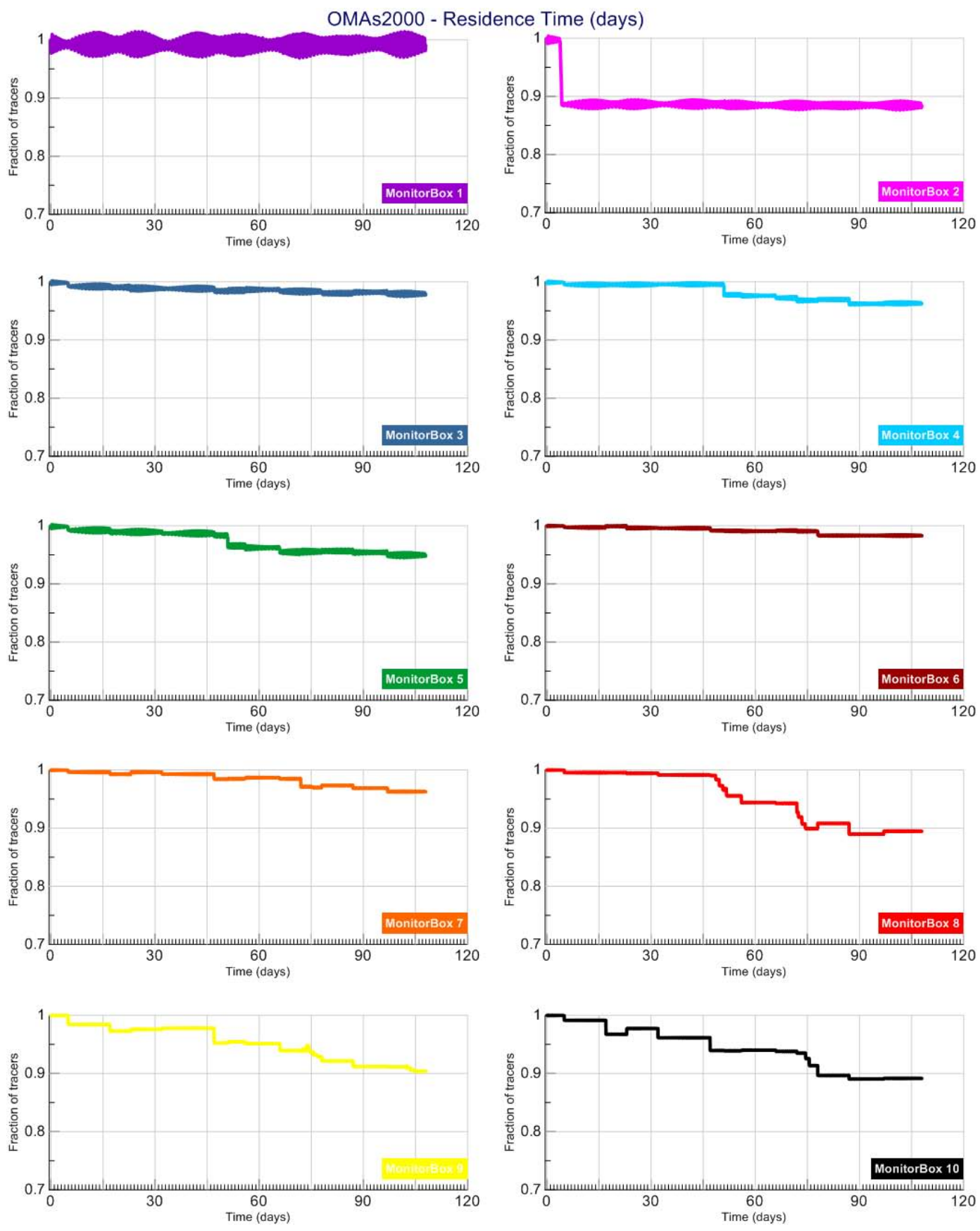

Fig. 4. The residence time of the $2000 \mu \mathrm{m}$ OMAs in each monitor box over the simulated period. The monitor boxes are set at increasing depths from box 1 to box 10: $59 \mathrm{~m}, 262 \mathrm{~m}, 357 \mathrm{~m}, 575 \mathrm{~m}, 331 \mathrm{~m}, 945 \mathrm{~m}, 1498 \mathrm{~m}, 2077 \mathrm{~m}, 2657 \mathrm{~m}$, and $3189 \mathrm{~m}$.

very active transport for the OMAs of different size classes. After 74 days, there was a sudden decrease in OMAs escaping from box 8 , and this loss was more pronounced for the $429 \mu \mathrm{m}$ (Fig. 3) and $4000 \mu \mathrm{m}$ (Fig. 5) than for the $2000 \mu \mathrm{m}$ OMAs (Fig. 4). The residence times of the $4000 \mu \mathrm{m}$ showed a significant depletion in box 9 (Fig. 5). On the 46th day of simulation, there was an abrupt decrease of aggregate fraction followed by another significant escape on the 74th day.
The 429 and $2000 \mu \mathrm{m}$ OMAs however showed a gradual and less pronounced depletion with time (Figs. 3 and 4). Box 10 at $3189 \mathrm{~m}$ depth showed a significant depletion in the residence time of the $4000 \mu \mathrm{m}$ OMAs on the 74th day (Fig. 5), whereas 429 and $2000 \mu \mathrm{m}$ OMAs presented a gradual and less pronounced depletion as was the case of box 9 (Figs. 3 and 4). 

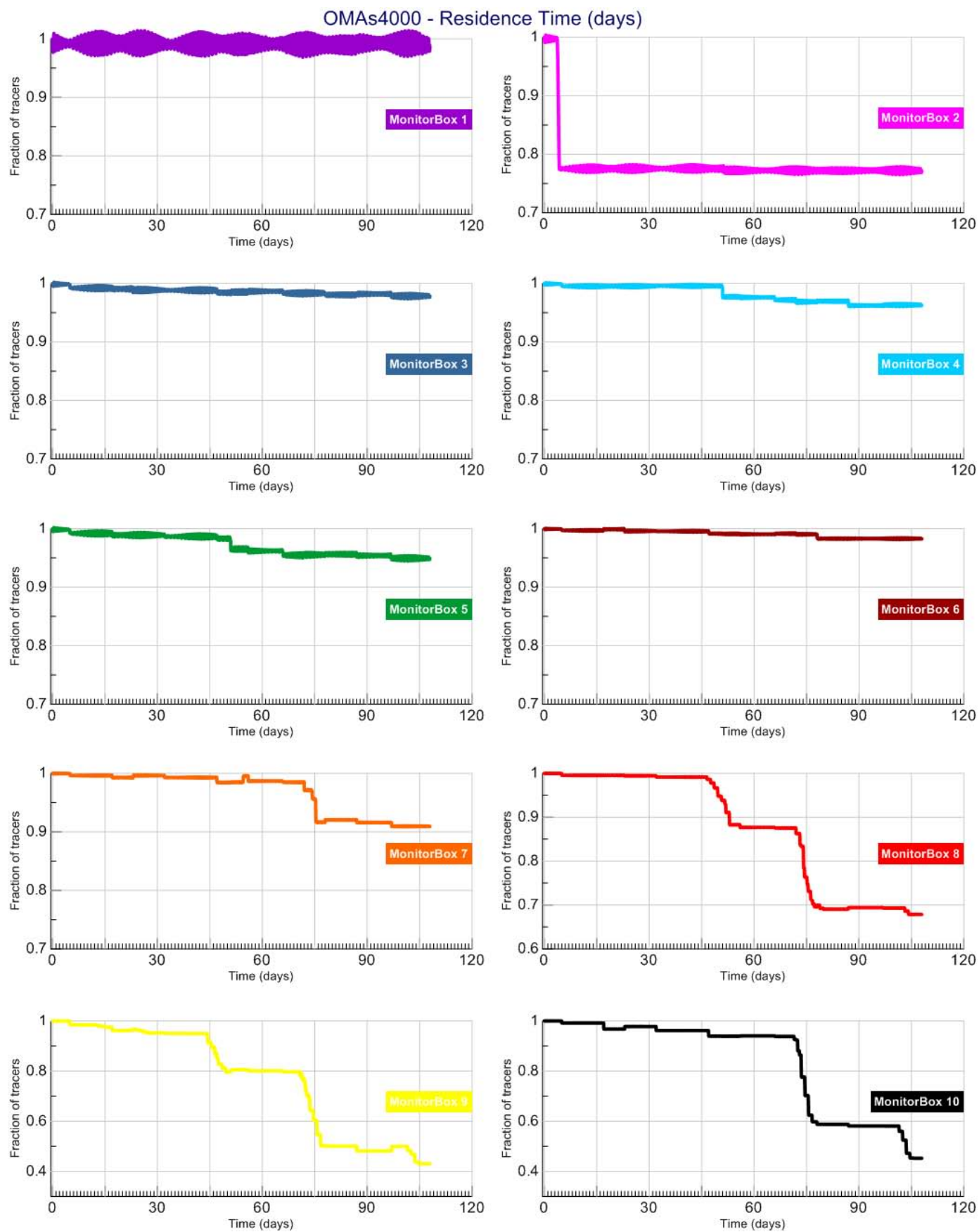

Fig. 5. The residence time of the $4000 \mu \mathrm{m}$ OMAs in each monitor box over the simulated period. The monitor boxes are set at increasing depths from box 1 to box 10: 59 m, 262 m, 357 m, 575 m, 331 m, 945 m, 1498 m, 2077 m, 2657 m, and $3189 \mathrm{~m}$.

\subsection{OMA dispersion patterns}

A higher percentage of OMAs escaped from the shelf break box 2 and from the offshore boxes 8,9 , and 10 for size classes 429 and $4000 \mu \mathrm{m}$ when compared to the $2000 \mu \mathrm{m}$ size class (Table 2). Very few $2000 \mu \mathrm{m}$ OMAs escaped from the boxes along the canyon axis depth gradient, with box 2 and 10 showing a slightly higher escape percentage. When com- paring the $429 \mu \mathrm{m}$ and $4000 \mu \mathrm{m}$ OMA size classes, a higher percentage of $429 \mu \mathrm{m}$ OMAs escaped from box 1 to 6 , while from box 7 to 10 the $4000 \mu \mathrm{m}$ OMAs showed higher percentages of escape (Table 2).

Figures 6 and 7 represent the dispersion patterns for the $429 \mu \mathrm{m}$ and $4000 \mu \mathrm{m}$ OMAs in each box predicted by the model for an initial period of 22 days, the half-life of fresh phytodetritus (Sun et al., 1991). The figures show the 


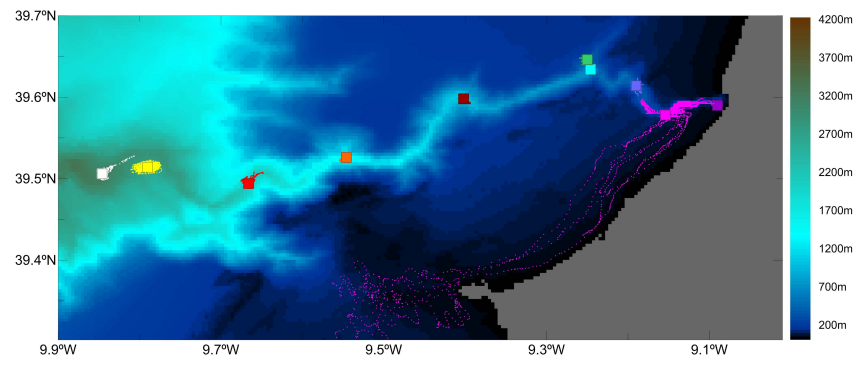

Fig. 6. Snapshot of the $429 \mu \mathrm{m}$ OMA dispersion patterns after 22 days of simulation.

aggregate trajectories along the depth gradient during that period. The $429 \mu \mathrm{m}$ OMAs from box 2 at the shelf break were dispersed and transported in different directions (Fig. 6). OMAs travelled southward along the coast with the Portugal current, up-canyon in the direction of the coast and downcanyon (Fig. 6). The $4000 \mu \mathrm{m}$ size class OMAs were only dispersed down-canyon (Fig. 7) for the first 22 days simulated. Within the lower canyon region, the $429 \mu \mathrm{m}$ OMAs from boxes 8 and 10 were mainly dispersed up-canyon after 22 days, with those from box 9 showing a symmetric dispersion on the up-down canyon direction (Fig. 6). The dispersion of the $4000 \mu \mathrm{m}$ OMAs from the same boxes was not appreciable when compared with the $429 \mu \mathrm{m}$ OMAs (Fig. 7). Boxes 1, 3, 4, 5, 6 and 7 for both 429 and $4000 \mu \mathrm{m}$ OMAs did not show considerable dispersion.

\subsection{OMA behaviour}

The $429 \mu \mathrm{m}$ OMAs at the shelf break (box 2) and in the lower region of the canyon (boxes 8,9 , and 10) travelled longer distances (Fig. 8) and at higher velocities (Fig. 10) than the $2000 \mu \mathrm{m}$ and $4000 \mu \mathrm{m}$ OMAs. The highest distance value for the $429 \mu \mathrm{m}$ was in box 2, while for the two classes of phytodetrital aggregates it was in box 9 (Fig. 8). The displacement was higher in box 2 for the 429 and $2000 \mu \mathrm{m}$ size classes and in box 2 and 9 for the $4000 \mu \mathrm{m}$ size class (Fig. 9). The velocities of phytodetrital aggregates were higher in box 9, while for the $429 \mu \mathrm{m}$ in box 2 (Fig. 10). The $2000 \mu \mathrm{m}$ OMAs travelled the shortest distance and at the lowest velocities. On average the $429 \mu \mathrm{m}$ OMAs travelled 2.5 times farther away and with a speed 8 times higher than the $2000 \mu \mathrm{m}$ and 2.2 times farther away and 7 times faster than the $4000 \mu \mathrm{m}$ OMAs. In terms of displacement, the $2000 \mu \mathrm{m}$ travelled a net distance $0.34 \mathrm{~km}$ and $0.47 \mathrm{~km}$ less than the $4000 \mu \mathrm{m}$ and $429 \mu \mathrm{m}$ OMAs respectively. OMAs at the remaining boxes generally showed short travelling distances, displacements and velocities.

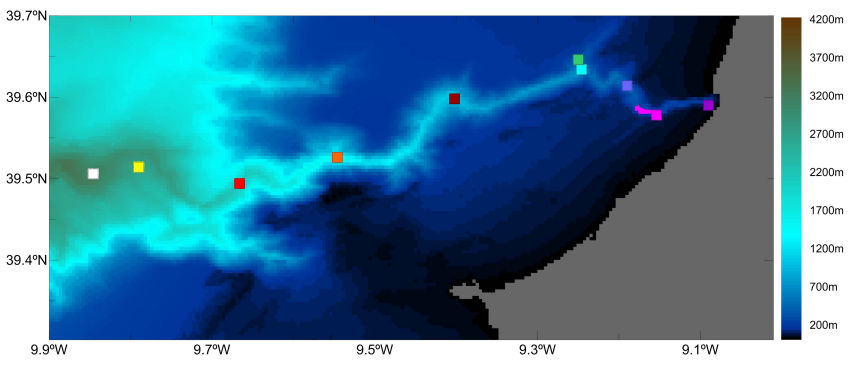

Fig. 7. Snapshot of the $4000 \mu \mathrm{m}$ OMA dispersion patterns after 22 days of simulation.

\section{Discussion}

The conceptual model of OMA transport drawn from the model results mostly agrees with what other authors have described for the Nazare canyon. This holds especially true for the $429 \mu \mathrm{m}$ sized particles. In comparison to the transport of small lithogenic particles (De Stigter et al., 2007), large aggregates do not travel over long distances due to their different transport behaviour. The different sections of the canyon show different patterns of resuspension, transport and deposition of OMAs. From the upper to middle canyon regions, tidal currents are an important mechanism of resuspension and transport of sedimentary particles (De Stigter et al., 2007), and the residence time of the OMAs showed a sinusoidal pattern for boxes 1 to 5 at the upper canyon (Figs. 3 5), also indicating a close match with the semidiurnal peaks of the tides (Vitorino et al., 2002).

The canyon head was characterized by active transport of OMAs, particularly the $429 \mu \mathrm{m}$ size class. Larger amounts of OMAs escaped from box 2 (Table 2) and travelled up to $168 \mathrm{~km}$ (Fig. 8), and at maximum velocities of $568 \mathrm{~km} \mathrm{yr}^{-1}$ (Fig. 10). Here, longest displacements (Fig. 9) and dispersion were observed within the canyon, up and down the canyon, as well as southwards along the coast (Fig. 6). A large percentage of the $4000 \mu \mathrm{m}$ size class OMAs also escaped from box 2, and showed long displacement (Fig. 9) and some dispersion down canyon (Fig. 7). However, these OMAs travelled at much lower velocities with maximum distances of $9.8 \mathrm{~km} \mathrm{yr}^{-1}$ and for much shorter distances of maximum values of $2.9 \mathrm{~km}$. At the canyon head, the $429 \mu \mathrm{m}$ OMAs exhibited the highest lateral carbon flux with the $4000 \mu \mathrm{m}$ class being the next. This active lateral transport could be associated with the formation of nepheloid layers at these depths (Van Weering et al., 2002; Oliveira et al., 2002; De Stigter et al., 2007).

In the middle of the upper canyon (from box 3 to 6), OMA transport slowed down as indicated by the small percentages of the three OMA classes escaping from the boxes (Table 2), the very high residence times in the canyon (Figs. 3-5), the lack of dispersion (Fig. 6 and 7), and no appreciable travel distances (Fig. 8) and displacements (Fig. 9), which occur at the slowest velocities (Fig. 10). Hence, the large amounts of 

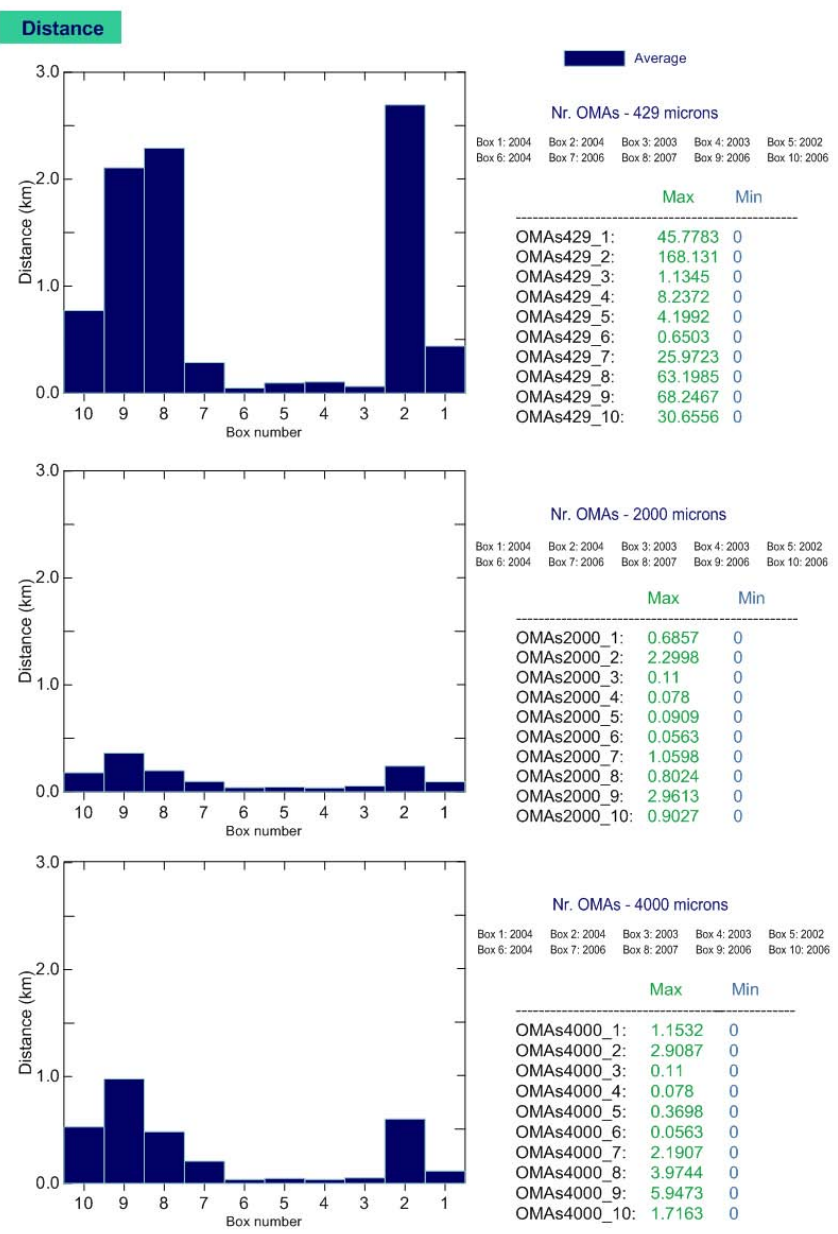

Fig. 8. Distance predicted by the model for the three classes of OMAs.

OMAs remaining in the boxes and the lack of lateral transport indicated that the transport of OMAs in this region is dominated by short travel times followed by rapid deposition due to their increased settling velocities. This supports the idea that this section of the canyon is a deposition area of sedimentary organic matter (Schmidt et al., 2001; Van Weering et al., 2002). The OMAs with the highest residence times were the 2000 and $4000 \mu \mathrm{m}$ sizes (Figs. 3-5), which barely moved as indicated by their extremely short distances, displacements and velocities (Figs. 8-10). Hence, these large phytodetrital aggregates are the major contributors in terms of carbon flux to the sediments at this region of the canyon, which may fuel the benthic communities with a food source. Although faunal abundances and biomass generally show a decreasing trend with increasing water depth, higher amounts of fresher phytodetritus and labile organic matter characterize this region of the canyon (García and Thomsen, 2008; Pusceddu et al., 2010), where the higher faunal abundances and biomasses have been found (García et al., 2007, Koho et al., 2007).

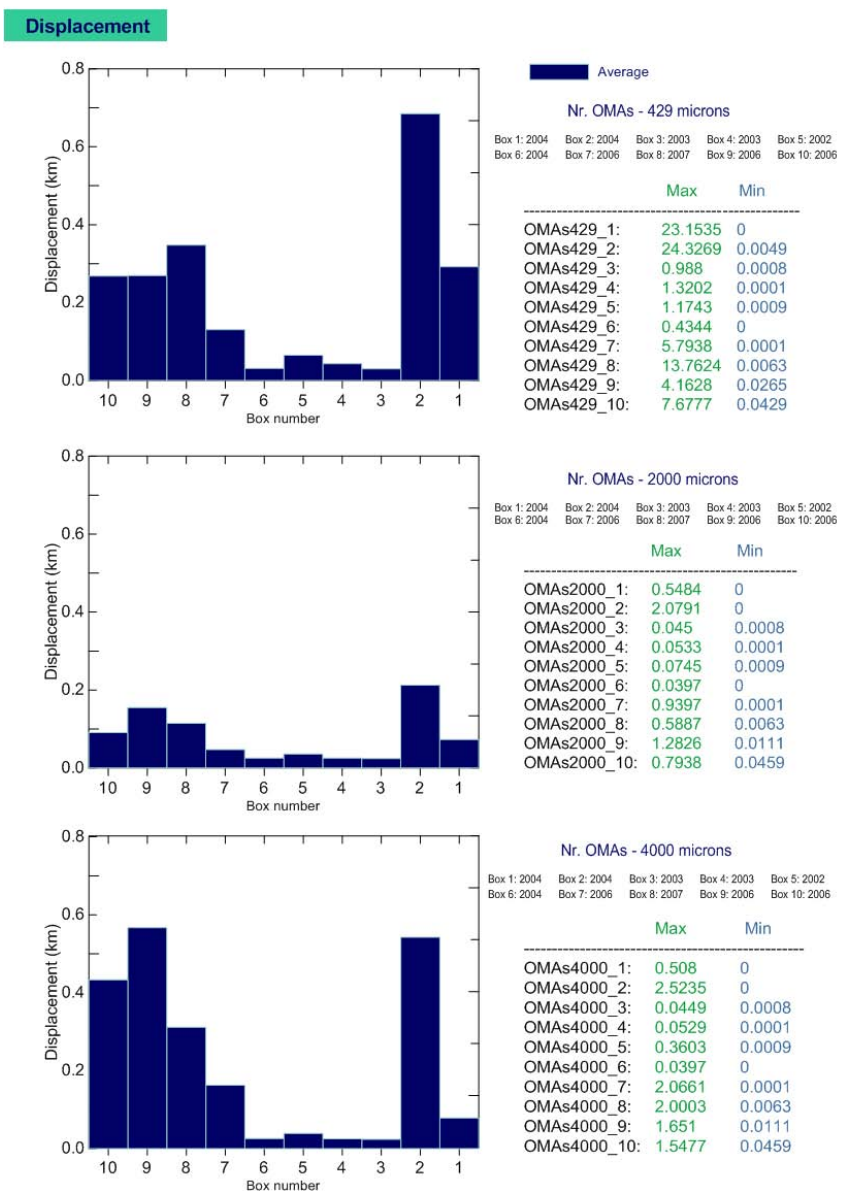

Fig. 9. Displacement predicted by the model for the three classes of OMAs.

Farther down, also within the middle upper canyon, the model simulations show a slight increase in the lateral carbon fluxes at box 7 at $1498 \mathrm{~m}$ depth. This box showed a slight increase in velocities (Fig. 10), displacements (Fig. 9) and distances (Fig. 8) of particularly the $429 \mu \mathrm{m}$ and $4000 \mu \mathrm{m}$ OMA size classes, and a slight increase of the percentages of particles escaping from the box (Table 2). We barely identify dispersion of OMAs though (Figs. 6 and 7), and the aggregates with $2000 \mu \mathrm{m}$ systematically show low travelling velocities, displacements, distances and box escape percentages. We therefore conclude that this region acts as a transitional zone and is mostly characterized by a depositional regime, but where a certain amount of lateral transport occurs. Indeed, favourable conditions for sediment resuspension have been described for this region of the canyon (De Stigter et al., 2007; Oliveira et al., 2007; Martín et al., 2011). High current speeds have been observed at $\sim 1600 \mathrm{~m}$ depth in combination with high mass fluxes of particulate matter (Martín et al., 2011), which may explain the slight increase of lateral transport in our results. The model simulations were only carried out for a spring period and do not consider the possible role 


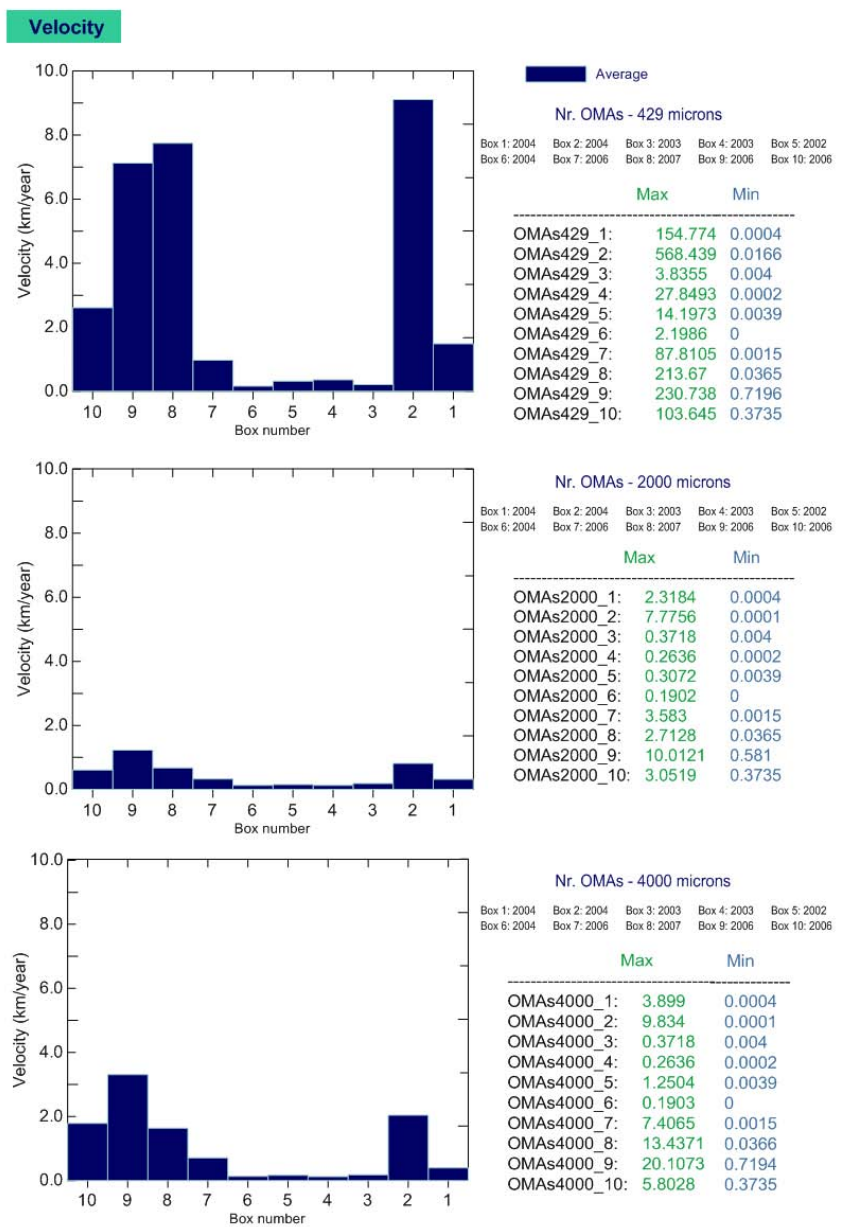

Fig. 10. Velocity predicted by the model for the three classes of OMAs.

of intermittent sediment gravity flows in the transport of material. Thus the OMA transport predictions could be underestimations. If the highly energetic winter conditions were taken into account, enhanced resuspension and transport of OMAs through this part of the canyon might have been more conspicuous. This could be further evaluated in future model simulations.

The offshore region of the canyon was characterized by resuspension of OMAs and acceleration of the transport. At boxes 8,9 and 10, the OMAs residence times were low (Figs. 3-5), accompanied by high escape percentages from the boxes, particularly of the $4000 \mu \mathrm{m}$ size class (Table 2). There was an increase in OMA travelling distances (Fig. 8), displacements (Fig. 9) and velocities (Fig. 10) that reached similar values to the ones observed at the canyon head (box 2). The $429 \mu \mathrm{m}$ size class was again the driver of the particle flux reaching maximum velocities of $230 \mathrm{~km} \mathrm{yr}^{-1}$ and distances of $68 \mathrm{~km}$ in box 9 (Figs. 10 and 8). The phytodetrital aggregates, particularly the $4000 \mu \mathrm{m}$, showed also an active transport but not as pronounced as the $429 \mu \mathrm{m}$. Box 10, located in the middle canyon $(3189 \mathrm{~m})$, showed a slight decrease in the carbon flux with average velocities ranging from $2.6 \mathrm{~km} \mathrm{yr}^{-1}$ to $0.6 \mathrm{~km} \mathrm{yr}^{-1}$ (Fig. 10) and average distances ranging from $0.8 \mathrm{~km}$ to $0.2 \mathrm{~km}$ (Fig. 8) for the three different OMA classes. These boxes were located between 2077 and $3189 \mathrm{~m}$ water depth in a steep section of the canyon under the influence of high bottom currents and internal waves (De Stigter et al., 2007; Martín et al., 2011). High current speeds and variable seasonal fluxes were observed in springsummer at $\sim 3300 \mathrm{~m}$ (Martín et al., 2011), which would explain the more active nature of this part of the canyon in terms of sediment resuspension and horizontal carbon flux.

\section{Conclusions}

Exploring the potential of the operational modelling, the MOHID-PCOMS was used to give the necessary boundary conditions to apply a hydrodynamic model in the Nazaré canyon. A lagrangian transport model was successfully coupled to the MOHID model, giving an overview of the OMA transport patterns along the Nazare canyon bottom depth. The model simulations were performed during the spring season when phytodetritus production is high. With respect to our original hypothesis, the model results show that, during the specific time of investigation (spring 2009), the canyon did not function as a conduit of organo-mineral aggregates to the deep sea. Rather, it acts as a temporary depocentre of sedimentary organic matter during spring conditions. Previous studies (De Stigter et al., 2007; Martín et al., 2011) indicate that this may not always be the case, and the canyon is an active conduit of sediment transport to the deep sea. The model results show that the carbon flux in the canyon is not constant and unidirectional within areas of resuspension, transport and deposition. For instance, large, carbon-rich aggregates with their specific transport behaviour are not exported but rather remain in a given area for long periods of time. These aggregates, however, are frequently resuspended into the BBL and therefore allow mineralization to occur under turbulent conditions of the BBL. This is in agreement with other studies carried out within the canyon. The differences between transport patterns of the median OMAs and phytodetrital aggregates were also predicted by the model, and the lateral transport of the larger OMAs is less pronounced than for the median OMAs resulting in the carbon deposition. On the other hand, the model results did not include the possible role of sediment gravity flows, and therefore may underestimate the rates of OMA transport. Nevertheless, the model could also be applied to evaluate the transport patterns of other substances in the canyon such as pollutants. Further studies are required to analyse the differences in the carbon flux transport in an autumn-winter season and the impact of the river discharges on the increasing carbon fluxes in Nazaré canyon. 
Acknowledgements. The research leading to these results has received funding from the European Community's Seventh Framework Programme (FP7/2007-2013) under the HERMIONE project, grant agreement no. 226354

The authors would like to thank the Instituto Hidrográfico (IH) and the National Oceanography Centre (NOC) for the bathymetric data provided for the study. Also thanks to A. Purser for proofreading the manuscript.

S. Pando, M. Juliano and L. Thomsen conceived and designed the experiments. S. Pando and M. Juliano performed the experiments. Analysis of the data was performed by S. Pando, M. Juliano, R. García and L. Thomsen. S. Pando, M. Juliano, P. A. de Jesus Mendes and L. Thomsen contributed reagents/materials/analysis tools. The paper was written by S. Pando and R. García.

Edited by: R. Serrão Santos

\section{References}

Abascal, A., Castanedo, S., Fernández, V., and Medina, R.: Backtracking drifting objects using surface currents from highfrequency (HF) radar technology, Ocean Dynam., 62, 10731089, doi:10.1007/s10236-012-0546-4, 2012.

Accornero, A., Picon, P., Bovée, F. d., Charrière, B., and Buscail, R.: Organic carbon budget at the sediment-water interface on the Gulf of Lions continental margin, Cont. Shelf Res., 23, 7992, doi:10.1016/S0278-4343(02)00168-1, 2003.

Amaro, T., Witte, H., Herndl, G. J., Cunha, M. R., and Billett, D. S. M.: Deep-sea bacterial communities in sediments and guts of deposit-feeding holothurians in Portuguese canyons (NE Atlantic), Deep-Sea Res. Pt. I, 56, 1834-1843, doi:10.1016/j.dsr.2009.05.014, 2009.

Arzola, R. G., Wynn, R. B., Lastras, G., Masson, D. G., and Weaver, P. P. E.: Sedimentary features and processes in the Nazaré and Setúbal submarine canyons, west Iberian margin, Mar. Geol., 250, 64-88, doi:10.1016/j.margeo.2007.12.006, 2008.

Braunschweig, F., Martins, F., Chambel, P., and Neves, R.: A methodology to estimate renewal time scales in estuaries: the Tagus Estuary case, Ocean Dynam., 53, 137-145, doi:10.1007/s10236-003-0040-0, 2003.

Canals, M., Puig, P., de Madron, X. D., Heussner, S., Palanques, A., and Fabres, J.: Flushing submarine canyons, Nature, 444, 354357, doi:10.1038/nature05271, 2006.

Carracedo, P., Torres-López, S., Barreiro, M., Montero, P., Balseiro, C. F., Penabad, E., Leitão, P. C., and Pérez-Muñuzuri, V.: Improvement of pollutant drift forecast system applied to the Prestige oil spills in Galicia Coast (NW of Spain): Development of an operational system, Mar. Pollut. Bull., 53, 350-360, doi:10.1016/j.marpolbul.2005.11.014, 2006.

Coelho, H. S., Neves, R. J. J., White, M., Leitão, P. C., and Santos, A. J.: A model for ocean circulation on the Iberian coast, J. Mar. Syst., 32, 153-179, doi:10.1016/s0924-7963(02)00032-5, 2002.

Cunha, M. R., Paterson, G. L. J., Amaro, T., Blackbird, S., De Stigter, H. C., Ferreira, C., Glover, A., Hilário, A., Kiriakoulakis, K., Neal, L., Ravara, A., Rodrigues, C. F., Tiago, Á., and Billett, D. S. M.: Biodiversity of macrofaunal assemblages from three
Portuguese submarine canyons (NE Atlantic), Deep-Sea Res. Pt. II, 58, 2433-2447, doi:10.1016/j.dsr2.2011.04.007, 2011.

de Jesus Mendes, P. A. and Thomsen, L.: Particle concentrations and physical parameters in surface sediments and aggregates from the Portuguese continental margin, doi:10.1594/PANGAEA.615183, 2007.

de Jesus Mendes, P. A., Maier, I., and Thomsen, L.: Effect of physical variables on particle critical erosion shear stress: Hydrostatic pressure, slope and changes in water density, Estuar. Coast. Shelf Sci., 75, 317-326, doi:10.1016/j.ecss.2007.04.035, 2007.

De Stigter, H. C., Boer, W., de Jesus Mendes, P. A., Jesus, C. C., Thomsen, L., van den Bergh, G. D., and van Weering, T. C. E.: Recent sediment transport and deposition in the Nazare Canyon, Portuguese continental margin, Mar. Geol., 246, 144 164, doi:10.1016/j.margeo.2007.04.011, 2007.

Dias, J. M., Lopes, J. F., and Dekeyser, I.: Lagrangian transport of particles in Ria de Aveiro lagoon, Portugal, Phys. Chem. Earth Pt. B, 26, 721-727, doi:10.1016/S1464-1909(01)00076-4, 2001.

Epping, E., van der Zee, C., Soetaert, K., and Helder, W.: On the oxidation and burial of organic carbon in sediments of the Iberian margin and Nazaré Canyon (NE Atlantic), Progr. Oceanogr., 52, 399-431, doi:10.1016/s0079-6611(02)00017-4, 2002.

García, R. and Thomsen, L.: Bioavailable organic matter in surface sediments of the Nazaré canyon and adjacent slope (Western Iberian Margin), J. Mar. Syst., 74, 44-59, doi:10.1016/j.jmarsys.2007.11.004, 2008.

García, R., Koho, K. A., De Stigter, H. C., Epping, E., Koning, E., and Thomsen, L.: Distribution of meiobenthos in the Nazare canyon and adjacent slope (Western Iberian Margin) in relation to sedimentary composition, Mar. Ecol.-Progr. Ser., 340, 207-220, 2007.

García, R., van Oevelen, D., Soetaert, K., Thomsen, L., De Stigter, H. C., and Epping, E.: Deposition rates, mixing intensity and organic content in two contrasting submarine canyons, Progr. Oceanogr., 76, 192-215, doi:10.1016/j.pocean.2008.01.001, 2008.

García, R., Thomsen, L., De Stigter, H. C., Epping, E., Soetaert, K., Koning, E., and Mendes, P. A. D.: Sediment bioavailable organic matter, deposition rates and mixing intensity in the Setubal-Lisbon canyon and adjacent slope (Western Iberian Margin), Deep-Sea Res. Pt. I, 57, 1012-1026, doi:10.1016/j.dsr.2010.03.013, 2010.

Huhn, F., von Kameke, A., Allen-Perkins, S., Montero, P., Venancio, A., and Pérez-Muñuzuri, V.: Horizontal Lagrangian transport in a tidal-driven estuary-Transport barriers attached to prominent coastal boundaries, Cont. Shelf Res., 39-40, 1-13, doi:10.1016/j.csr.2012.03.005, 2012.

Ingels, J., Kiriakoulakis, K., Wolff, G. A., and Vanreusel, A.: Nematode diversity and its relation to the quantity and quality of sedimentary organic matter in the deep Nazaré Canyon, Western Iberian Margin, Deep-Sea Res. Pt. I, 56, 1521-1539, doi:10.1016/j.dsr.2009.04.010, 2009.

Koho, K. A., Kouwenhoven, T. J., De Stigter, H. C., and van der Zwaan, G. J.: Benthic foraminifera in the Nazaré Canyon, Portuguese continental margin: Sedimentary environments and disturbance, Mar. Micropaleontol., 66, 27-51, doi:10.1016/j.marmicro.2007.07.005, 2007.

Lastras, G., Arzola, R. G., Masson, D. G., Wynn, R. B., Huvenne, V. A. I., Hühnerbach, V., and Canals, M.: Geomorphology 
and sedimentary features in the Central Portuguese submarine canyons, Western Iberian margin, Geomorphology, 103, 310329, doi:10.1016/j.geomorph.2008.06.013, 2009.

Leitão, P., Coelho, H., Santos, A., and Neves, R.: Modelling the main features of the Algarve coastal circulation during July 2004: A downscaling approach, J. Atmos. Ocean Sci., 10, 421-462, doi:10.1080/17417530601127704, 2005.

Malhadas, M. S., Silva, A., Leitão, P. C., and Neves, R.: Effect of the Bathymetric Changes on the Hydrodynamic and Residence Time in Obidos Lagoon (Portugal), J. Coast. Res., 56, 549-553, 2009.

Martins, F., Leitão, P., Silva, A., and Neves, R.: 3D modelling in the Sado estuary using a new generic vertical discretization approach, Oceanol. Acta, 24, S51-S62, 2001.

Martín, J., Palanques, A., Vitorino, J., Oliveira, A., and De Stigter, H. C.: Near-bottom particulate matter dynamics in the Nazaré submarine canyon under calm and stormy conditions, DeepSea Res. Pt. II, 58, 2388-2400, doi:10.1016/j.dsr2.2011.04.004, 2011.

Masson, D. G., Huvenne, V. A. I., De Stigter, H. C., Wolff, G. A., Kiriakoulakis, K., Arzola, R. G., and Blackbird, S.: Efficient burial of carbon in a submarine canyon, Geology, 38, 831-834, doi:10.1130/g30895.1, 2010.

Mateus, M.: A process-oriented model of pelagic biogeochemistry for marine systems. Part I: Model description, J. Mar. Syst., 94, 78-89, doi:10.1016/j.jmarsys.2011.11.008, 2012.

Mateus, M., Riflet, G., Chambel, P., Fernandes, L., Fernandes, R., Juliano, M., Campuzano, F., de Pablo, H., and Neves, R.: An operational model for the West Iberian coast: products and services, Ocean Sci., 8, 713-732, doi:10.5194/os-8-713-2012, 2012.

Monaco, A., Durrieu de Madron, X., Radakovitch, O., Heussner, S., and Carbonne, J.: Origin and variability of downward biogeochemical fluxes on the Rhone continental margin (NW mediterranean), Deep-Sea Res. Pt. I, 46, 1483-1511, doi:10.1016/S0967-0637(99)00014-X, 1999.

Oliveira, A., Vitorino, J., Rodrigues, A., Jouanneau, J. M., Dias, J. A., and Weber, O.: Nepheloid layer dynamics in the northern Portuguese shelf, Progr. Oceanogr., 52, 195-213, doi:10.1016/s0079-6611(02)00006-x, 2002.

Oliveira, A., Santos, A. I., Rodrigues, A., and Vitorino, J.: Sedimentary particle distribution and dynamics on the Nazaré canyon system and adjacent shelf (Portugal), Mar. Geol., 246, 105-122, doi:10.1016/j.margeo.2007.04.017, 2007.

Pusceddu, A., Bianchelli, S., Canals, M., Sanchez-Vidal, A., De Madron, X. D., Heussner, S., Lykousis, V., De Stigter, H., Trincardi, F., and Danovaro, R.: Organic matter in sediments of canyons and open slopes of the Portuguese, Catalan, Southern Adriatic and Cretan Sea margins, Deep-Sea Res. Pt. I, 57, 441457, doi:10.1016/j.dsr.2009.11.008, 2010.

Quaresma, L. S., Vitorino, J., Oliveira, A., and da Silva, J.: Evidence of sediment resuspension by nonlinear internal waves on the Western Portuguese mid-shelf, Mar. Geol., 246, 123-143, doi:10.1016/j.margeo.2007.04.019, 2007.

Santos, A., Martins, H., Coelho, H., Leitao, P., and Neves, R.: A circulation model for the European ocean margin, Appl. Mathemat. Model., 26, 563-582, 2002.

Santos, A. J. P., Nogueira, J., and Martins, H.: Survival of sardine larvae off the Atlantic Portuguese coast: a preliminary numerical study, ICES J. Mar. Sci., 4, 634-644, 2005.
Saraiva, S., Pina, P., Martins, F., Santos, M., Braunschweig, F., and Neves, R.: Modelling the influence of nutrient loads on Portuguese estuaries, Hydrobiologia, 587, 5-18, doi:10.1007/s10750-007-0675-9, 2007.

Schmidt, S., De Stigter, H. C., and van Weering, T. C. E.: Enhanced short-term sediment deposition within the Nazaré Canyon, North-East Atlantic, Mar. Geol., 173, 55-67, doi:10.1016/s00253227(00)00163-8, 2001.

Sun, M., Aller, R. C., and Lee, C.: Early diagenesis of chlorophylla in Long Island Sound sediments: A measure of carbon flux and particle reworking, J. Mar. Res., 49, 379-401, doi:10.1357/002224091784995927, 1991.

Thomsen, L.: Processes in the benthic boundary layer at continental margins and their implication for the benthic carbon cycle, J. Sea Res., 41, 73-86, doi:10.1016/s1385-1101(98)00039-2, 1999.

Thomsen, L. and Graf, G.: Benthic boundary layer characteristics of the continental margin of the Western Barents Sea, Oceanol. Acta, 17, 597-607, 1995.

Thomsen, L. and Gust, G.: Sediment erosion thresholds and characteristics of resuspended aggregates on the Western European continental margin, Deep-Sea Res. Pt. I, 47, 1881-1897, doi:10.1016/s0967-0637(00)00003-0, 2000.

Thomsen, L. and Ritzrau, W.: Aggregates studies in the benthic boundary layer at a continental margin, J. Sea Res., 36, 143-146, doi:10.1016/s1385-1101(96)90784-4, 1996.

Thomsen, L. and van Weering, T. C. E.: Spatial and temporal variability of particulate matter in the benthic boundary layer at the N.W. European Continental Margin (Goban Spur), Progr. Oceanogr., 42, 61-76, doi:10.1016/S0079-6611(98)00028-7, 1998.

Thomsen, L., van Weering, T., and Gust, G.: Processes in the benthic boundary layer at the Iberian continental margin and their implication for carbon mineralization, Progr. Oceanogr., 52, 315-329, doi:10.1016/s0079-6611(02)00013-7, 2002.

Tyler, P., Amaro, T., Arzola, R., Cunha, M. R., De Stigter, H., Gooday, A., Huvenne, V., Ingels, J., Kiriakoulakis, K., Lastras, G., Masson, D., Oliveira, A., Pattenden, A., Vanreusel, A., Van Weering, T., Vitorino, J., Witte, U., and Wolff, G.: Europe's Grand Canyon Nazare Submarine Canyon, Oceanography, 22, 46-57, 2009.

Vale, L. M. and Dias, J. M.: Coupling of a Lagrangian particle tracking module to a numerical hydrodynamic model: Simulation of pollution events inside an eastuarine port area, J. Coast. Res., SI 64 (Proceedings of the 11th International Coastal Symposium 2011), 1609-1613, 2011.

Van Oevelen, D., Soetaert, K., Garcia, R., De Stigter, H. C., Cunha, M. R., Pusceddu, A., and Danovaro, R.: Canyon conditions impact carbon flows in food webs of three sections of the Nazaré canyon, Deep-Sea Res. Pt. II, 58, 2461-2476, doi:10.1016/j.dsr2.2011.04.009, 2011.

Van Weering, T. C. E., De Stigter, H. C., Boer, W., and de Haas, H.: Recent sediment transport and accumulation on the NW Iberian margin, Progr. Oceanogr., 52, 349-371, doi:10.1016/S00796611(02)00015-0, 2002.

Vitorino, J., Oliveira, A., Jouanneau, J. M., and Drago, T.: Winter dynamics on the northern Portuguese shelf. Part 1: physical processes, Progr. Oceanogr., 52, 129-153, doi:10.1016/s00796611(02)00003-4, 2002. 
Weaver, P. P. E. and Gunn, V.: Introduction to the special issue: HERMES-Hotspot Ecosystem Research on the Margins of European Seas, Oceanography, 1, 12-15, 2009.

Weaver, P. P. E., Canals, M., and Trincardi, F.: EUROSTRATAFORM Special Issue of Marine Geology, Mar. Geol., 234, 1-2, doi:10.1016/j.margeo.2006.09.001, 2006.
Wollast, R. and Chou, L.: Ocean Margin EXchange in the Northern Gulf of Biscay: OMEX I. An introduction, Deep-Sea Res. Pt. II, 48, 2971-2978, doi:10.1016/S0967-0645(01)00029-7, 2001. 